\title{
Accumulation and Health Risk Assessment of PAHs in Radish
}

\author{
Jin Guo ${ }^{1}$, Chao Chai ${ }^{1 *}$, Wei Ge², Lusheng Zeng', Juan Wu', \\ Dan Xiang ${ }^{1}$, Xiaomei Zhang ${ }^{1}$ \\ ${ }^{1}$ Qingdao Engineering Research Center for Rural Environment, Qingdao Agricultural University, \\ Qingdao, China \\ ${ }^{2}$ College of Life Sciences, Qingdao Agricultural University, Qingdao, China
}

Received: 8 September 2017

Accepted: 8 December 2017

\begin{abstract}
Three kinds of soil with different levels of polycyclic aromatic hydrocarbon (PAH) contamination were collected, and diesel was added to soil to prepare two kinds of diesel-contaminated soil. The radish was planted in five kinds of soil through a pot experiment, and the concentration and composition of PAHs in radish were analyzed using high-performance liquid chromatography with an ultraviolet and fluorescent detector. The PAH contribution in aboveground parts of radish from atmospherically deposited particulates was studied, and the health risk of ingesting contaminated radish was assessed. Results showed that PAH concentrations (196.2-982.6 ng/g) in the parts of radish found underground were significantly higher than in aboveground parts (129.7-556.7 ng/g, $p<0.05)$. Predominant PAH compounds in radish were the 3and 4-ring PAHs, accounting for 78.1-92.7\%. In general, the values of root concentration factors (RCFs: 0.30-0.55) were significantly higher than shoot concentration factors (SCFs: $0.19-0.39, p<0.05$ ). Atmospherically deposited particles contributed less than $1 \%$ of the PAHs in aboveground parts of radish, which indicated two things: the atmospheric particles had a slight effect on the PAH content in aboveground parts of radish, and the soil contributed more to PAH accumulation in aboveground parts of radish than the particles. The total toxicity equivalence quotient in radish grown in diesel-contaminated soil samples was higher than in other types of soil. Ingestion of radish planted in five kinds of soil had no carcinogenic risk to children, adolescents, and seniors; whereas ingestion of radish from heavily contaminated and diesel-contaminated soil samples had carcinogenic risks to adults.

This study highlights the accumulation and potential health risks associated with cultivation and consumption of radish in soil with different contamination levels and sources of PAHs.
\end{abstract}

Keywords: PAHs, accumulation, health risk assessment, radish

*e-mail: chaichao1999@126.com 


\section{Introduction}

Polycyclic aromatic hydrocarbons (PAHs) are composed of two or more aromatic rings of carbon and hydrogen atoms and are considered a large class of ubiquitous persistent organic pollutants in the environment [1-3]. PAHs mainly come from burning coal and fossil fuel, industrial and vehicle emissions, petroleum spill petroleum chemical industry, coking, and smelting [4]. PAHs drew concern for their genotoxic and carcinogenic potential [5-7]. The U.S. Environmental Protection Agency (USEPA) has classified 16 priority PAHs, seven of which are potential carcinogens [8].

Many studies have shown that vegetables can accumulate PAHs from polluted environments, such as in contaminated soil, as reported by Zhang et al. [9]. The concentration of PAHs in lettuce, potato, and carrot increased with the rising concentrations in soils [10]. PAHs mainly accumulate in a pathway from the soil to the root and shoot of vegetables. Yang et al. [11] also suggested that phenanthrene accumulation in the shoot mainly comes from root transport. The main factors affecting PAH uptake by plants were the initial PAH concentration in soil, plant species, and soil microbial community. However, Wan et al. [12] showed that the concentration of PAHs in 77 kinds of vegetables and in soils are not significantly correlated. PAH concentration in plant aerial tissue is positively correlated with the concentration in air; PAHs in atmospheric vapor may be an important source of PAHs in five vegetable species [13]. PAHs in vegetables may be harmful to human health because the main route of human exposure to environmental pollutants is food consumption, which accounts for $90 \%$ of intake compared to inhalation and skin contact [14-16]. Therefore, studying PAH accumulation in vegetables is important.

Most studies previously conducted on plant PAH uptake and accumulation focused on leafy vegetables [17-
18]. Waqas et al. [19] reported that cabbages, followed by radishes in Mardan, had the highest concentration of PAHs. These results indicate that PAH accumulation amounts in root vegetables is higher than in leafy vegetables due to wastewater irrigation. A few studies have studied the effect of atmospherically deposited particulates on PAH accumulation in root vegetables; thus, more attention should be provided for this aspect. Although studies carried out so far on health risk assessment of PAHs in vegetables grown in agricultural soils contaminated by coal and wood combustion are many [20-21], few studies have investigated the health risk assessment of PAHs in edible vegetables grown in diesel-contaminated soils. Diesel is widely used as one of the most vital petroleum products and contains paraffins, olefins, naphthenes, PAHs, and other groups [22]. About $800 \mathrm{t}$ petroleum are released annually into environments in the world, leading to the contamination of PAHs in soils [23]. Therefore, the health risk assessment of PAHs in vegetables grown in diesel-contaminated soils should be of concern.

Radish (Raphanus sativus L.) belongs to the family of Brassicaceae and presents high nutritional and pharmaceutical value. Many countries have cultivated varieties of radish, one of the most common vegetables; hence, radish was selected as the representative root vegetable for this study. This study aimed to investigate the concentration and profile of PAHs in radish planted in soil with different contamination levels and sources of PAHs and analyze the relationship among PAH concentrations of radish, soils, and atmospherically deposited particulates. A discussion of the contribution of PAHs to radish of atmospherically deposited particulates and an assessment of the health risk of PAHs follow. The results of the study may be very helpful in elucidating accumulation of PAHs in root vegetables and protecting residents from the potential health risks through vegetable ingestion caused by different PAH contamination sources - especially diesel contamination.

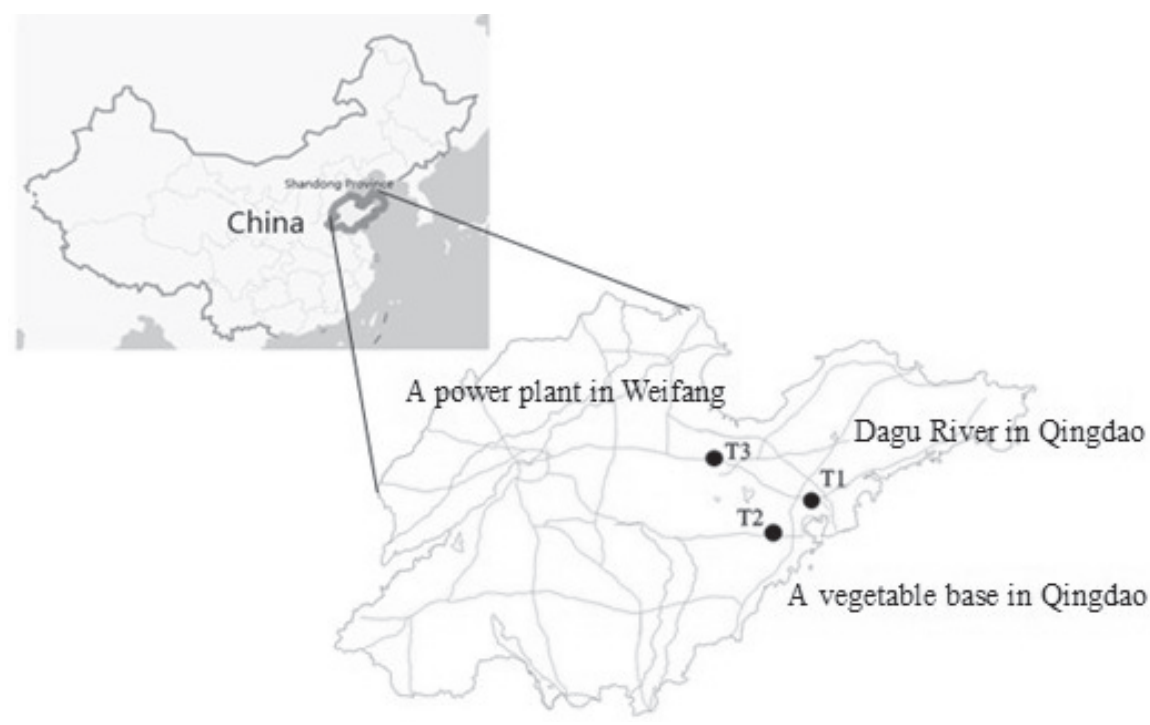

Fig. 1. Schematic map showing the soil sampling sites. 


\section{Materials and Methods}

\section{Collecting and Preparing Soils}

The soils were collected in 2016 in Shandong Province from three sites, including along the Dagu River in Qingdao (T1, Fluvo-aquic soils), at a vegetable base in Qingdao (T2, Brown earths), and from an agricultural field near a power plant in Weifang (T3, Brown earths; Fig. 1.). The $\mathrm{pH}$ values of $\mathrm{T} 1, \mathrm{~T} 2$, and $\mathrm{T} 3$ soils were 6.1, 5.8, and 6.0, respectively, and the concentrations of organic matter were $5.3,15.7$, and $16.9 \mathrm{~g} / \mathrm{kg}$, respectively. Varying amounts of diesel were added to soil T1 to prepare diesel-contaminated soils $\mathrm{T} 4$ and T5. The proportions of diesel in $\mathrm{T} 4$ and $\mathrm{T} 5$ soils were approximately $10 \mathrm{~mL} / \mathrm{kg}$ and $15 \mathrm{~mL} / \mathrm{kg}$, respectively. Then, T4 and T5 soils were aged for eight weeks. Soils were air dried in the dark and then sieved through a $2 \mathrm{~mm}$ mesh for a pot experiment.

\section{Design of Pot Experiment}

Radish seeds were planted in T1-T5 soils. Each pot was filled with $3.5 \mathrm{~kg}$ of soil $(<2 \mathrm{~mm})$, and four replicates per treatment were prepared. Deionized water was used for irrigation throughout the entire process, which lasted 35 days. The atmospherically deposited particles were collected with silica gel placed at shoot height to analyze the PAH contribution of atmospherically deposited particles to shoot tissues [24]. The soils were covered with uncontaminated sand to prevent possible root contact with atmospheric deposition. After 35 days, the soil and plant samples were collected, freeze-dried, and ground to determine PAH concentrations.

\section{PAH Extraction and Analysis}

Two grams of soil and $10 \mathrm{~mL}$ dichloromethane (DCM) were placed in the centrifuge tube and sonicated for one hour. Then the mixture was centrifuged at $4,000 \mathrm{rpm}$ for 10 minutes. The same extraction process was repeated. The extracts were combined and concentrated to $1 \mathrm{~mL}$. The solvent underwent purification through silica gel column (the upper was $4 \mathrm{~g}$ anhydrous sodium sulfate, the lower was $4 \mathrm{~g}$ silica gel) with elution of hexane and DCM (11 mL, v:v, 1:1). The eluent was concentrated to near dryness and solvent-exchanged to $2.0 \mathrm{~mL}$ methanol for analysis. A wash with $10 \mathrm{~mL}$ of DCM in the glass centrifuge tube removed atmospherically deposited particles. This method was consistently used with soil.

Plant samples $(2$ g) were extracted through ultrasonication for 10 min with a solution of acetone and hexane (v:v, 1:1). The process was repeated thrice and centrifuged at 2,500 r/min for $5 \mathrm{~min}$. The solvent was purified through acidic silica gel column (the upper was $4 \mathrm{~g}$ anhydrous sodium sulfate, the middle was $4 \mathrm{~g}$ sulfuric acid silica gel, the lower was $4 \mathrm{~g}$ silica gel) with $20 \mathrm{~mL}$ of 1:1 (v/v) elution of hexane and DCM. The eluent was concentrated to near dryness and solvent-exchanged to $2.0 \mathrm{~mL}$ methanol for analysis.

PAHs were analyzed using high-performance liquid chromatography equipped with an ultraviolet and fluorescent detector (HPLC-UV-FLD, Shimadzu). An Inertsil ODS-P column $(250 \times 4.6 \mathrm{~mm}, 3.5 \mu \mathrm{m}$ particle size, $1,000 \mathrm{~nm}$ pore size) was used to separate 16 PAHs. The mobile phase was methanol-water (80:20, v:v), and the flow rate was $1.0 \mathrm{~mL} / \mathrm{min}$. Column temperature was $40^{\circ} \mathrm{C}$ and the injection volume was $20 \mu \mathrm{L}$.

A composite standard solution of 16 PAHs, including naphthalene (NAP), acenaphthene (ACE), acenaphthylene (ACY), fluorene (FLU), phenanthrene (PHE), anthracene (ANT), fluoranthene (FLA), pyrene (PYR), benz(a) anthracene (BaA), chrysene (CHR), benzo(b)fluoranthene $(\mathrm{BbF})$, benzo(k)fluoranthene $(\mathrm{BkF})$, benzo(a)pyrene (BaP), dibenzo(a,h)anthracene (DBA), indeno(1,2,3cd)pyrene (IPY), and benzo(ghi)perylene (BPE) was purchased from AccuStandard Company (USA). All solvents were HPLC grade.

\section{Quality Assurance and Control}

Data quality was controlled by blank experiment and parallel sample analysis. No detectable amount of PAHs was found in the blank operation. The recovery of NAP was $62 \%$, and the other PAHs were $86 \% \pm 15 \%$. Quantitative analysis was performed using a five-point calibration curve method. The correlation coefficients of each calibration curve were higher than 0.999. The standard mixture was analyzed for every 10 samples to determine instrument stability and confirm the calibration curve. The limits of detection were in the range of $0.07 \mathrm{ng} / \mathrm{g}$ to $2 \mathrm{ng} / \mathrm{g}$.

\section{Data Analysis}

\section{Shoot and Root Transfer Factors}

The soil-to-plant transfer is one of the main ways in which pollutants enter the food chain. Root concentration factors (RCFs) and shoot concentration factors ( $\mathrm{SCFs}$ ) were calculated as follows:

$$
\begin{aligned}
& \text { (i) } \mathrm{RCF}=\frac{\mathrm{C}_{\text {underground }}}{\mathrm{C}_{\text {soil }}} \\
& \text { (ii) } \mathrm{SCF}=\frac{\mathrm{C}_{\text {aboveground }}}{\mathrm{C}_{\text {soil }}}
\end{aligned}
$$

...where $\mathrm{C}_{\text {underground, }}, \mathrm{C}_{\text {aboveground, }}$ and $\mathrm{C}_{\text {soil }}$ represent $\mathrm{PAH}$ concentrations in the underground parts of radish, aboveground parts of radish, and soil based on dry weight, respectively [24]. 


\section{Contributions of PAHs in Atmospherically Deposited Particulates}

Theradish leafsurfacearea and mass of atmospherically deposited particulates were calculated by Fismes et al. [11]. The contribution of PAHs in aboveground parts of radish from atmospherically deposited particulates was calculated as follows:

$$
\mathrm{Dd}=\mathrm{SA} \times \mathrm{AdDd}
$$

...where Dd is the daily dust deposition quality on aboveground parts of radish (mg), SA is the surface area of the radish leaf $\left(\mathrm{m}^{2}\right)$, and AdDd is average daily dust deposition $\left(\mathrm{mg} / \mathrm{m}^{2}\right)$.

$$
\mathrm{TAd}=\mathrm{Dd} 3+\frac{\mathrm{Dd} 5}{2} \times 35 \mathrm{~d}
$$

...where TAd, Dd3, and Dd5 represent the total average dry dust deposition on aboveground parts of radish (mg) and daily dust deposition on aboveground parts of radish $(\mathrm{mg})$ at 3 and 5 weeks, respectively.

$$
\text { ATd }- \text { tPAHs }=\mathrm{C}-\text { tPAHs } \times \text { TAd } \times 10^{-6}
$$

...where ATd - tPAHs is the average total deposition of the total PAHs $(\mu \mathrm{g})$ on aboveground radish parts, and C - tPAHs represents the average total PAH concentrations in the dust (ng/g) [24].

$$
\text { Contribution }=\frac{\mathrm{ATd}-\mathrm{tPAHs}}{\mathrm{C}_{\text {aboveground }} \times M_{\text {aboveground }}}
$$

...where $\mathrm{M}_{\text {aboverround }}$ represents the mass of aboveground parts of radish based on dry weight.

\section{Health Risk Assessment}

Toxicity equivalence quotient $\left(\mathrm{TEQ}_{\mathrm{BaP}}\right)$ was shown as $\mathrm{BaP}$ equivalent concentrations and was calculated by multiplying the concentration of each PAH in the radish by its TEF based on the USEPA [25].

$$
\mathrm{TEQ}_{\text {Bap }}=\mathrm{C}_{\mathrm{i}} \times \mathrm{TEF}_{\mathrm{i}}
$$

...where $\mathrm{C}_{i}$ is the concentration of individual $\mathrm{PAH}$, and $\mathrm{TEF}_{\mathrm{i}}$ is the corresponding toxicity equivalence factor.

The incremental lifetime cancer risk (ILCR) of the dietary exposure to PAHs was also calculated based on Equation 8 [26].
$\mathrm{ILCR}=\mathrm{TEF}_{\text {Bap }} \times \mathrm{E}_{\mathrm{f}} \times \mathrm{IR} \times \mathrm{EF} \times \mathrm{ED} \times \mathrm{SF} \times \mathrm{CF} /(\mathrm{BW} \times \mathrm{AT})$

...where $\mathrm{E}_{\mathrm{f}}$, a conversion factor of 0.009 , was the weight of fresh radish converted to dry weight; IRs (amount of radish ingested) of children, adolescents, adults, and seniors were $0.0043,0.0072,0.011$, and $0.010 \mathrm{~kg} / \mathrm{d}$, respectively [27]; SF was the oral cancer slope factor, $\mathrm{BaP}(7.3 \mathrm{mg} / \mathrm{kg} / \mathrm{d}$ ) [28]; ED factors (duration of exposure) of children, adolescents, adults, and seniors were 7, 7, 43, and 10, respectively [26, 29]; BWs (average body weight) of children, adolescents, adults, and seniors, were 23.6, 48, 62, and $62 \mathrm{~kg}$, respectively; AT or average time was 27,740 days [30]; EF or exposure frequency was 365 days/year; and $\mathrm{CF}$ is the conversion factor $\left(10^{-6} \mathrm{mg} / \mathrm{ng}\right)$.

\section{Data Analysis}

The analysis was conducted through SPSS version 20.0 using ANOVA with the least significant difference method (at $\alpha \leq 0.05$ level) to calculate the significant statistical difference in PAH concentrations. The correlation analysis was carried out using the Spearman correlation analysis.

\section{Result and Discussion}

\section{Concentration and Profile of PAHs in Soils}

The concentrations and relative contributions of PAHs in soils are shown in Table 1. The total concentra-tions of the 16 PAHs ( $\left.\Sigma_{16} \mathrm{PAHs}\right)$ ranged from 376.7-2,509.1 $\mathrm{ng} / \mathrm{g}$ in soils. $\Sigma_{16} \mathrm{PAHs}$ in T3 soil was the highest, and $\Sigma_{16} \mathrm{PAHs}$ in the four other soils were below $1,000 \mathrm{ng} / \mathrm{g}$. Relative to the standard of PAH concentration in soils [31], T1 soil was weakly contaminated (200-600 ng/g); T2, T4, and T5 soils were contaminated $(600-1,000 \mathrm{ng} / \mathrm{g})$; and T3 soil was heavily contaminated $(>1,000 \mathrm{ng} / \mathrm{g})$.

The profile of PAHs in the five soil samples was slightly different. In T1 soil, PYR, ACE, and ACY were the principal compounds. Chief compounds in $\mathrm{T} 2$ soil were ACY, FLA, and PYR. Meanwhile, PHE and FLU were predominant in T3 soil, and ACE, ACY, and ANT were predominant in T4 and T5 soils. Despite the difference in profiles, the contributions of 3- and 4-ring PAHs were relatively high in all soils. The contributions of 3-ring PAHs in T1, T3, T4, and T5 soil accounted for $42.7 \%, 75.2 \%, 47.6 \%$, and $51.8 \%$ of the $\Sigma_{16} \mathrm{PAHs}$, respectively, whereas the contribution of 4-ring PAHs in T2 soils accounted for $46.3 \%$ of the $\Sigma_{16}$ PAHs.

$\Sigma_{16} \mathrm{PAHs}$ in $\mathrm{T} 2$ and $\mathrm{T} 4$ soil were roughly similar, but the profiles of PAH in T2 and T4 soil were slightly different. The contribution of BkF, BaP, BPE, and IPY in $\mathrm{T} 4$ soil was higher than $\mathrm{T} 2$ soil, thereby suggesting that the contributions of 5- and 6-ring PAHs in T4 soil were higher 
than T2 soil. The PAH profiles in diesel-contaminated soils of T4 and T5 were similar. The contribution of BaP in T4 (8.8\%) and T5 (8.7\%) was higher than T1 (4.6\%), T2 (2.0\%), and T3 (1.4\%) soil, thereby suggesting that the contribution of 5-ring PAHs in T4 and T5 soils was higher than T1, T2, and T3. Pan et al. [32] also reported that the concentration of $\mathrm{CHR}$ or $\mathrm{BaP}$ was high in dieselcontaminated soils.

The concentration of carcinogenic PAHs $\left(\Sigma_{7} \mathrm{PAH}\right.$, including $\mathrm{BaA}, \mathrm{CHR}, \mathrm{BbF}, \mathrm{BaP}, \mathrm{BkF}, \mathrm{DBA}$, and IPY) [33] ranged 107.1-315.4 $\mathrm{ng} / \mathrm{g}$, and $\Sigma_{7} \mathrm{PAHs}$ in dieselcontaminated soils of T4 and T5 were higher than those in other soils. In this study, diesel was added to $\mathrm{T} 1$ soil to prepare the diesel-contaminated soils of T4 and $\mathrm{T} 5$, and the contribution of carcinogenic PAHs in T4 $(36.9 \%)$ and T5 $(32.9 \%)$ soil were higher than T1 (28.4\%) soil. Similar results were reported in previous studies. Qi et al. [34] reported that the concentrations of carcinogenic PAHs ranged 47,033.2-287,922.3 ng/g in petroleum-contaminated soils of Shengli Oil Field, and the contributions of carcinogenic PAHs in petroleumcontaminated soils (75.9-78.6\%) were high.

\section{PAH Concentrations in Radish}

$\Sigma_{16}$ PAHs in radish are shown in Fig. 2. $\Sigma_{16}$ PAHs found in buried parts of radish planted in five soils ranged 196.2-982.6 $\mathrm{ng} / \mathrm{g}$, while those in parts aboveground ranged from $129.7-556.7 \mathrm{ng} / \mathrm{g}$. $\Sigma_{16}$ PAHs in radish planted in $\mathrm{T} 3$ soil were the highest, whereas $\mathrm{T} 1$ soil had the lowest concentration. Plant uptake of PAHs was via fine roots [35], and there are a lot of fine roots in buried parts of radish. $\Sigma_{16}$ PAHs in parts found underground were significantly higher than those in parts aboveground $(p<0.05)$. These results are consistent with those obtained from previous studies [36-37].

$\Sigma_{16}$ PAHs in radish had a significantly positive correlation with those in soil $(\mathrm{p}<0.01)$. The correlation coefficients between the two parts of the radish and the soil were 0.976 and 0.956 , respectively. The correlation coefficient between the parts of radish found aboveground and underground was 0.956 . These results are consistent with those obtained from previous studies. The uptake and

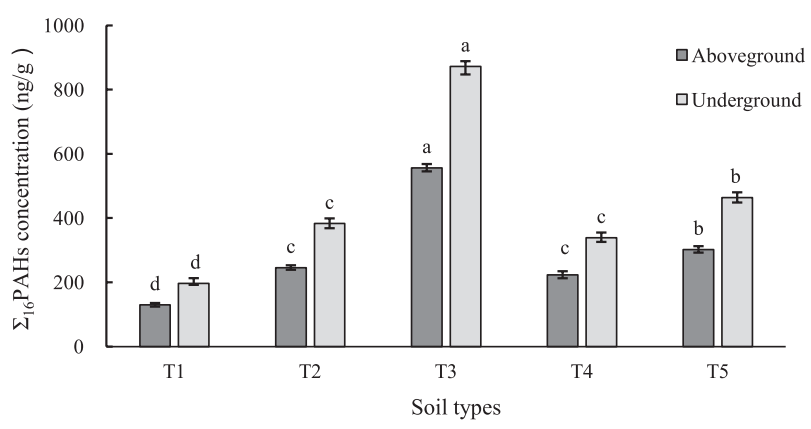

Fig. 2. $\Sigma_{16}$ PAHs in radish planted in different soils (letters indicate significant differences between the different groups $(p<0.05)$, and the same letters show the insignificant difference). accumulation of PHE, PLA, and BaP by pakchoi cabbage was reported, and the concentrations in roots or shoots increased as PAH concentrations in soil increased [38]. $\Sigma_{16}$ PAHs in four kinds of leafy vegetables were positively correlated with PAH concentrations in soil [39]. Shen et al. [40] reported that $\Sigma_{16}$ PAHs in plants are positively correlated with soil and air concentrations and posited that $\Sigma_{16}$ PAHs in the air of the sampling area were higher $(4,050.0 \mathrm{ng} / \mathrm{g})$ than in the soil $(724.0 \mathrm{ng} / \mathrm{g})$. However, Zhang et al. [41] found that $\Sigma_{16}$ PAHs in lettuce, cucumber, cabbage, and other vegetables were not correlated to those in the soil possibly due to the low PAH concentration in soil $(233.0 \mathrm{ng} / \mathrm{g})$. The contamination level of PAHs in soils may affect the relationship of PAH concentrations in vegetables and soils.

Compared with $\Sigma_{16}$ PAHs in soils in Table 1, $\Sigma_{16}$ PAHs in radish were significantly lower than those in the soil $(p<0.01)$. Khana et al. reported that low molecular weight PAH (LMW-PAHs) concentrations in the roots and leaves of lettuce was two to three times and four to five times lower than those in soils, respectively [24]. Meanwhile, high molecular weight PAH (HMW-PAHs) concentrations in roots and leaves were two to three times and 10 to 16 times lower than those in soils.

\section{Profile of PAHs in Radish}

The relative contributions of 3- and 4-ring PAHs were high in radish planted in five soils (Fig. 3) with underground portions contributing $81.0-92.7 \%$ and parts aboveground contributing 78.1-91.1\%. The contribution of 4-ring PAHs was high in radish planted in T2 soil, and the contribution of 3-ring PAHs was high in radish planted in $\mathrm{T} 1, \mathrm{~T} 3, \mathrm{~T} 4$, and $\mathrm{T} 5$ soils; whereas the contributions of 5- and 6-ring PAHs were relatively low at $3-19 \%$. Previous studies found that the contributions of 2- and 3-ring PAHs in the roots and leaves of winter wheat on oily sludge-amended soil were $57.8 \%$ and $53.5 \%$, respectively [42]. In addition, the contributions of 3- and 4-ring PAHs in pine needles ranged from $65-95 \%$ [43]. Gao et al. [44] also reported that the contributions of 3-ring PAHs in carrots, spinach, and eggplant were $65.9 \%, 66.2 \%$, and $64.5 \%$, respectively. Therefore, 2-4-ring PAHs are dominant in vegetables and other plants.

Because of the high contribution of $\mathrm{BaP}$ in dieselcontaminated soils of $\mathrm{T} 4$ and $\mathrm{T} 5$, the contributions of $\mathrm{BaP}$ in radish planted in diesel-contaminated soils of $\mathrm{T} 4$ and $\mathrm{T} 5$ is high. PAH profiles of T2 and T4 soils were slightly different, and the contributions of 5- and 6-ring PAHs in radish planted in T4 soil were higher than T2 soil. Therefore, the contributions of PAHs in radish were similar to those in soil.

A significant positive correlation exists between 2-, 3 -, and 4-ring PAHs in radish and those in soils $(r>0.940, p$ $<0.05$ ), whereas no significant correlation exists between 5-and 6-ring PAHs in radish and those in soils ( $\mathrm{p}>0.05$ ). Zhang et al. [45] found that PAHs in soils affected PAHs in vegetables, and a highly similar distribution of PAHs 
Table 1. PAH concentrations (ng/g) and relative contributions of individual PAH compounds or of PAHs with different numbers of rings to total PAHs (\%).

\begin{tabular}{|c|c|c|c|c|c|c|c|c|c|c|}
\hline \multirow[t]{2}{*}{ PAHs } & \multicolumn{2}{|c|}{$\mathrm{T} 1$} & \multicolumn{2}{|c|}{$\mathrm{T} 2$} & \multicolumn{2}{|c|}{$\mathrm{T} 3$} & \multicolumn{2}{|c|}{$\mathrm{T} 4$} & \multicolumn{2}{|c|}{ T5 } \\
\hline & $\begin{array}{c}\text { Concen- } \\
\text { tration }\end{array}$ & $\begin{array}{l}\text { Contribu- } \\
\text { tion }\end{array}$ & $\begin{array}{l}\text { Concen- } \\
\text { tration }\end{array}$ & $\begin{array}{l}\text { Contribu- } \\
\text { tion }\end{array}$ & $\begin{array}{l}\text { Concen- } \\
\text { tration }\end{array}$ & $\begin{array}{l}\text { Contribu- } \\
\text { tion }\end{array}$ & $\begin{array}{c}\text { Concen- } \\
\text { tration }\end{array}$ & $\begin{array}{l}\text { Contribu- } \\
\text { tion }\end{array}$ & $\begin{array}{c}\text { Concen- } \\
\text { tration }\end{array}$ & $\begin{array}{l}\text { Contribu- } \\
\text { tion }\end{array}$ \\
\hline NAP & 1.9 & 0.5 & 26.9 & 3.8 & 32.9 & 1.3 & 10.2 & 1.4 & 15.8 & 1.6 \\
\hline ACY & 39.0 & 10.4 & 190.9 & 26.6 & 54.3 & 2.2 & 100.7 & 14.2 & 159.8 & 16.7 \\
\hline $\mathrm{ACE}$ & 40.8 & 10.8 & 30.4 & 4.2 & 305.5 & 12.2 & 81.8 & 11.5 & 115.3 & 12.0 \\
\hline FLU & 27.5 & 7.3 & 52.1 & 7.3 & 371.5 & 14.8 & 34.5 & 4.9 & 68.6 & 7.2 \\
\hline PHE & 26.5 & 7.0 & 19.8 & 2.8 & 847.9 & 33.8 & 27.2 & 3.8 & 42.5 & 4.4 \\
\hline ANT & 27.1 & 7.2 & 4.4 & 0.6 & 306.6 & 12.2 & 93.4 & 13.2 & 110.9 & 11.6 \\
\hline FLA & 33.5 & 8.9 & 119.4 & 16.7 & 144.9 & 5.8 & 27.5 & 3.9 & 46.1 & 4.8 \\
\hline PYR & 48.5 & 12.9 & 103.9 & 14.5 & 255.3 & 10.2 & 50.8 & 7.2 & 53.1 & 5.5 \\
\hline $\mathrm{BaA}$ & 2.5 & 0.7 & 60.3 & 8.4 & 37.7 & 1.5 & 53.7 & 7.6 & 59.0 & 6.2 \\
\hline CHR & 22.8 & 6.1 & 47.9 & 6.7 & 32.7 & 1.3 & 47.6 & 6.7 & 51.4 & 5.4 \\
\hline $\mathrm{BbF}$ & 26.7 & 7.1 & 29.7 & 4.1 & 37.7 & 1.5 & 41.4 & 5.8 & 38.3 & 4.0 \\
\hline $\mathrm{BkF}$ & 10.0 & 2.7 & 4.5 & 0.6 & 18.6 & 0.7 & 22.6 & 3.2 & 40.5 & 4.2 \\
\hline $\mathrm{BaP}$ & 17.3 & 4.6 & 14.4 & 2.0 & 35.6 & 1.4 & 62.7 & 8.8 & 83.4 & 8.7 \\
\hline DBA & 3.7 & 1.0 & 0.9 & 0.1 & 0.8 & 0.0 & 2.6 & 0.4 & 4.3 & 0.4 \\
\hline BPE & 24.8 & 6.6 & 6.3 & 0.9 & 17.4 & 0.7 & 21.7 & 3.1 & 31.3 & 3.3 \\
\hline IPY & 24.1 & 6.4 & 4.8 & 0.7 & 9.7 & 0.4 & 31.1 & 4.4 & 38.5 & 4.0 \\
\hline $\begin{array}{l}\text { 2-ring } \\
\text { PAHs }\end{array}$ & 1.9 & 0.5 & 26.9 & 3.8 & 32.9 & 1.3 & 10.2 & 1.4 & 15.8 & 1.6 \\
\hline $\begin{array}{l}\text { 3-ring } \\
\text { PAHs }\end{array}$ & 160.9 & 42.7 & 297.4 & 41.5 & $1,885.7$ & 75.2 & 337.6 & 47.6 & 497.1 & 51.8 \\
\hline $\begin{array}{l}\text { 4-ring } \\
\text { PAHs }\end{array}$ & 107.3 & 28.5 & 331.5 & 46.3 & 470.7 & 18.8 & 179.6 & 25.3 & 209.7 & 21.9 \\
\hline $\begin{array}{l}\text { 5-ring } \\
\text { PAHs }\end{array}$ & 57.6 & 15.3 & 49.5 & 6.9 & 92.8 & 3.7 & 129.3 & 18.2 & 166.6 & 17.4 \\
\hline $\begin{array}{l}\text { 6-ring } \\
\text { PAHs }\end{array}$ & 48.9 & 13.0 & 11.2 & 1.6 & 27.2 & 1.1 & 52.8 & 7.4 & 69.8 & 7.3 \\
\hline$\Sigma_{7} \mathrm{PAH}$ & 107.1 & 28.4 & 162.5 & 22.6 & 172.8 & 6.8 & 261.7 & 36.9 & 315.4 & 32.9 \\
\hline$\Sigma_{16} \mathrm{PAH}$ & 376.7 & 100.0 & 716.6 & 100.0 & $2,509.1$ & 100.0 & 709.5 & 100.0 & 958.8 & 100.0 \\
\hline
\end{tabular}

in vegetables and soils was observed. The significant contributions of 3- and 4-ring PAHs in five soils in this study led to a large proportion of 3- and 4-ring PAHs in radish. LMW-PAHs more easily accumulate due to their considerable vapor pressure, water solubility, and bioavailability [46-48]. PAH accumulation was reduced with the increase of the number of benzene rings in molecular PAHs [49]. Physicochemical properties of the soil are factors affecting PAH profiles in vegetables. Zhang et al. [50] found that the high concentration of 3 -ring PAHs in vegetables was related to their responsive interaction with fulvic acid, the high concentration of 3-ring PAHs in soil, and high bio-accessibility.

The average proportion of carcinogenic PAHs in radish ranged $15.6-30.7 \%$. The average proportion of carcinogenic PAHs in radish planted in T4 soil (30.7\%) and T5 soil (26.6\%) was higher than in radish planted in T1, T2, and T3 soils due to the higher proportion of carcinogenic PAHs in T4 and T5 soils (Table 1). Khillare et al. [51] reported that carcinogenic PAHs accounted for $8 \%$ and $11 \%$ of total PAHs in spinach and radish planted in the soils around thermal power plants, respectively. Wang et al. [52] found that the proportions of carcinogenic PAHs were $13.9 \%$ and $7.5 \%$ in Chinese cabbage and Indian lettuce planted in the agricultural soils, respectively. Therefore, the proportion of carcinogenic PAHs in vegetables grown in diesel-contaminated soil is higher than that in other soils due to the higher proportion of carcinogenic PAHs in diesel-contaminated soil. 

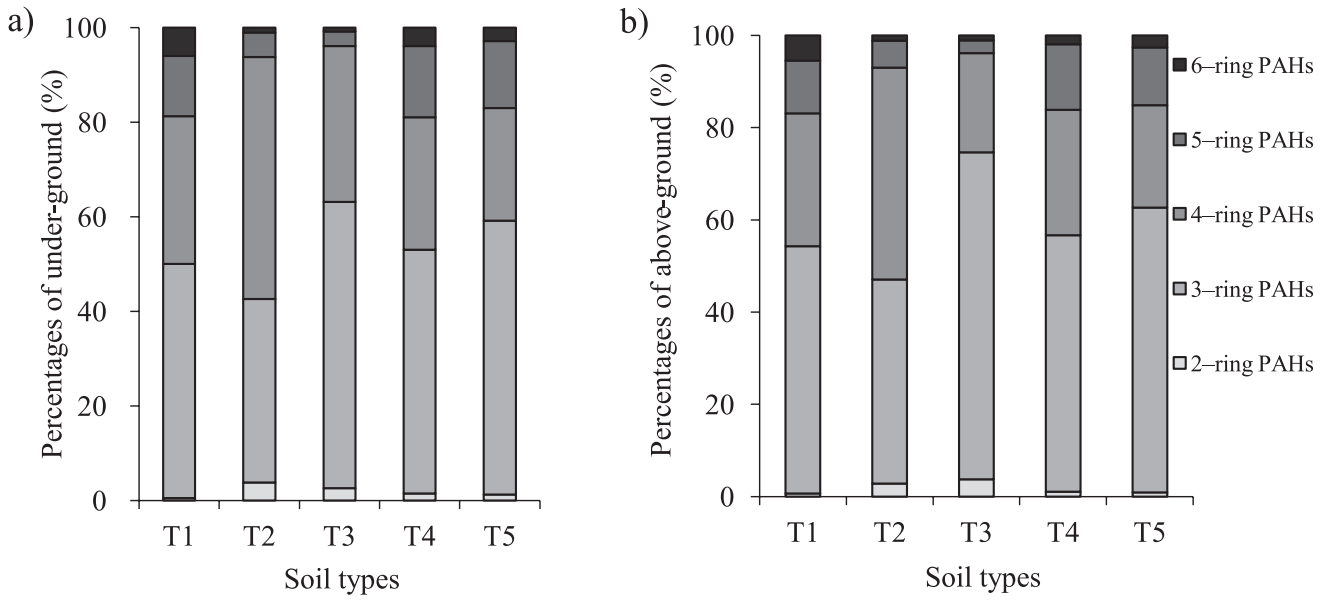

Fig. 3. Relative contributions of PAHs in radish (\%): a) underground and b) aboveground.

\section{Contribution of PAHs in Atmospherically Deposited Particulates}

$\Sigma_{16}$ PAHs in atmospherically deposited particles were $1,269.3 \mathrm{ng} / \mathrm{g}$. The concentration of 4-ring PAHs was 467.6 $\mathrm{ng} / \mathrm{g}$, followed by 5 - and 6-ring PAHs with concentrations of $331.6 \mathrm{ng} / \mathrm{g}$ and $279.9 \mathrm{ng} / \mathrm{g}$, respectively (Fig. 4.). HMWPAHs accounted for nearly $80 \%$ of total 16 PAHs in atmospherically deposited particles. Similar results have been reported in previous studies. Duan et al. [53] found that the proportion of 4-ring PAHs in the atmospheric particles of Beijing was the largest (48.7\%), followed by 5-ring PAHs (32.5\%) and 6-ring PAHs (14.9\%). The PAHs in the atmospheric particles in spring, autumn, and winter of Huainan City were mainly 4-6-ring PAHs, accounting for $81.6 \%, 84.4 \%$, and $85.6 \%$ of total PAHs, respectively [54]. Atmospheric LMW-PAHs are mainly concentrated in the gas phase, while HMW-PAHs are concentrated in the particulate phase [55-58].

Total PAH deposition amounts in the five soils were, respectively, $0.0015,0.0005,0.0003,0.0014$, and 0.0012 $\mu \mathrm{g}$. The proportions of PAHs from deposited particulates to total PAHs in aboveground parts of radish planted in T1-T5 soils were $0.71 \%, 0.46 \%, 0.28 \%, 0.29 \%$, and $0.13 \%$, respectively, thereby suggesting that the atmospheric

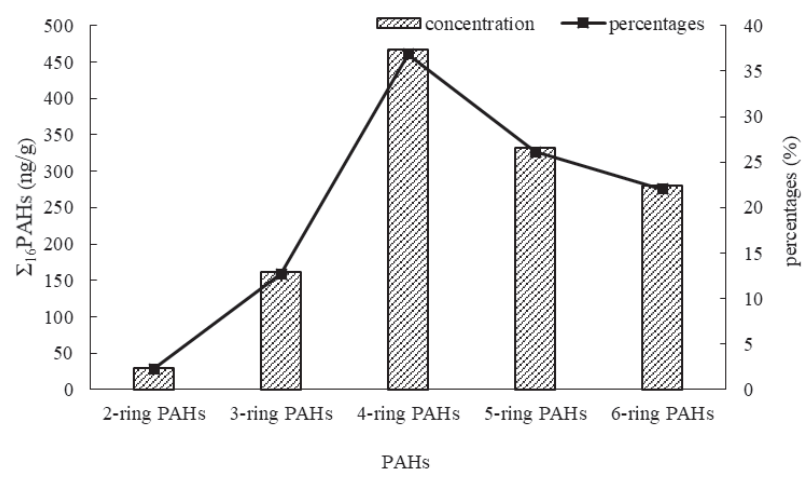

Fig. 4. Concentrations and percentages of PAHs in atmospherically deposited particulates. particles had a slight effect on the concentrations of PAHs in aboveground parts of radish. Fismes et al. and Khan et al. $[10,24]$ also showed that the PAH contribution of atmospheric particles for lettuce, which was found to be less than $1.2 \%$, was negligible.

Many studies have reported that PAHs in soils play an important role in PAHs in plants. PAH accumulation in vegetables increases with PAH concentrations in soil [38], suggesting that uptake of PAHs through roots is the main pathway by which PAHs can enter plants from the soil [59-60]. However, Wang [61] reported that atmospheric absorption pathway was the main way for PAHs into the vegetables. Xiong etal. [62] showed that PAH contributions from air transferred into the cabbages was higher than that of PAHs from soil near a coking production base. The composition of PAHs in plant tissues was similar to that of air in an industrial area, indicating that a gaseous path considerably contributes to PAH accumulation [13]. The relative level of PAHs in the soil and atmosphere may account for this difference. The present study was carried out in Qingdao in spring. PAH concentration in the atmosphere surrounding Qingdao during spring and summer was lower than in other seasons, and the concentration of $\mathrm{BaP}$ in the atmosphere was lower than that of China's national standard, thereby explaining the low concentration of PAHs in the atmosphere [63]. By comparison, soils in this study were PAH-contaminated soil, with T3 soil being heavily contaminated. This condition may explain the slight effect of atmospheric particles on PAHs in radish.

\section{Transfer Factors of PAHs in Radish}

The transfer factors of PAHs in radish planted in different soils are presented in Table 2. The values of RCFs $(0.30-0.55)$ were significantly higher than those of SCFs $(0.19-0.39, \mathrm{p}<0.05)$. PAH transport from the roots to the stems and leaves is difficult because PAHs cannot reach the root epidermis inside the xylem [64]. For parts of the radish found underground, the RCF of ANT and FLA was high (0.61), while the RCF value of BPE was low 
Table 2. Transfer factors of PAHs in radish planted in different soils.

\begin{tabular}{|c|c|c|c|c|}
\hline PAHs & \multicolumn{2}{|c|}{ RCFs } & \multicolumn{2}{c|}{ BCFs } \\
\hline & Mean & S.D. & Mean & S.D. \\
\hline 2-ring & 0.45 & 0.23 & 0.37 & 0.18 \\
\hline 3-ring & 0.54 & 0.13 & 0.37 & 0.10 \\
\hline 4-ring & 0.55 & 0.06 & 0.39 & 0.06 \\
\hline 5-ring & 0.37 & 0.07 & 0.22 & 0.06 \\
\hline 6-ring & 0.30 & 0.05 & 0.19 & 0.08 \\
\hline
\end{tabular}

at 0.28 . For parts of radish aboveground, the BCF of FLA was the highest (0.49). The values of RCFs and BCFs with 2-4 ring PAHs were significantly higher than 5-6-ring PAHs $(\mathrm{p}<0.05)$ due to their considerable vapor pressure, water solubility, and bioavailability. In comparison, the 5-6-ring PAHs were preferentially associated with organic matter in soil and were strongly associated with black carbon [46-48], which means that incorporating 5-6-ring PAHs into plant cells is difficult [65]. The availability and uptake rate of 5-6-ring PAHs decreases, resulting in low RCFs and BCFs [10, 24, 49].

\section{Health Risk Assessment}

Table 3 shows the $\mathrm{TEQ}_{\mathrm{BaP}}$ of PAHs in the edible parts of radish planted in five soils. $\mathrm{TEQ}_{\mathrm{BaP}}$ in radish ranged from
$12,102.2 \mathrm{ng} / \mathrm{kg}$ to $46,621.6 \mathrm{ng} / \mathrm{kg}$. PAH concentrations in $\mathrm{T} 3$ soil were the highest, but the BaP concentrations in radish of $\mathrm{T} 4$ and $\mathrm{T} 5$ soils were significantly higher than in $\mathrm{T} 3$ soils, and the BkF, BbF, and DBA concentrations in radish of $\mathrm{T} 5$ soil were significantly higher than those in other soils $(\mathrm{p}<0.05)$. The $\mathrm{TEQ}_{\mathrm{BaP}}$ in radish planted in T4 (34727.6 ng/kg) and T5 (46621.6 ng/ $/ \mathrm{kg})$ soils was significantly higher than in other soils $(\mathrm{p}<0.05)$.

In this study, the ILCR of PAHs in the edible parts of radish planted in T1-T5 soils for children, adolescents, and seniors was lower than $1.0 \times 10^{-6}$. The ILCR of PAHs for adults in radish planted in T1-T5 soils were $7.8 \times 10^{-7}$, $8.0 \times 10^{-7}, 1.1 \times 10^{-6}, 2.2 \times 10^{-6}$, and $3.0 \times 10^{-6}$, respectively (Table 4). The ILCR values of acceptable risk level is at $1.0 \times 10^{-6}$. If the ILCR value is lower than $1.0 \times 10^{-6}$, then no risk exists. An ILCR value between $1.0 \times 10^{-6}$ and $1.0 \times 10^{-4}$ denotes potential risk, and ILCR values higher than $1.0 \times 10^{-4}$ are markers of serious carcinogenic risk $[26,29,66]$. No carcinogenic risks through the ingestion of radish planted in T1-T5 soils exist for children, adolescents, and seniors, whereas carcinogenic risks through ingestion of radish planted in T3, T4, and T5 soils were present for adults.

Different sources of pollution in different regions indicate that PAHs in the study area had different exposures compared to those of other studies. Compared with the food exposure risk in other areas, ILCR for PAH dietary exposure through spinach, radish, cowpea, bottle gourd, bitter gourd, and ridge gourd investigated in Delhi was $3.4 \times 10^{-6}$, and the ILCR values for adults were

Table 3. $\mathrm{TEQ}_{\mathrm{BaP}}(\mathrm{ng} / \mathrm{kg})$ in the edible parts of radish planted in five soils.

\begin{tabular}{|c|c|c|c|c|c|c|}
\hline & TEFs & $\mathrm{T} 1$ & $\mathrm{~T} 2$ & $\mathrm{~T} 3$ & $\mathrm{~T} 4$ & $\mathrm{~T} 5$ \\
\hline NAP & 0.001 & 0.3 & 14.6 & 25.2 & 5.3 & 6.1 \\
\hline $\mathrm{ACY}$ & 0.001 & 20.2 & 87.8 & 17.3 & 45.2 & 92.3 \\
\hline ACE & 0.001 & 24.9 & 18.4 & 84.0 & 41.4 & 48.2 \\
\hline FLU & 0.001 & 16.6 & 27.7 & 103.4 & 19.6 & 38.4 \\
\hline PHE & 0.001 & 15.7 & 11.6 & 291.5 & 17.3 & 25.1 \\
\hline ANT & 0.01 & 200.0 & 29.9 & 991.5 & 589.0 & 768.4 \\
\hline FLA & 0.001 & 18.4 & 71.0 & 93.9 & 16.5 & 29.9 \\
\hline PYR & 0.001 & 30.8 & 59.1 & 76.5 & 26.6 & 29.0 \\
\hline $\mathrm{BaA}$ & 0.1 & 74.0 & $3,924.8$ & $2,720.6$ & $2,695.8$ & $2,618.3$ \\
\hline CHR & 0.01 & 117.0 & 264.8 & $1,262.5$ & 292.5 & 304.7 \\
\hline $\mathrm{BbF}$ & 0.1 & $1,152.0$ & $1,167.3$ & $1,335.0$ & $1,693.5$ & $1,948.7$ \\
\hline $\mathrm{BkF}$ & 0.1 & 420.0 & 194.6 & 834.9 & 842.8 & $1,048.9$ \\
\hline $\mathrm{BaP}$ & 1 & $7,620.0$ & $6,050.1$ & $8,028.4$ & $25,970.0$ & $36,720.0$ \\
\hline DBA & 1 & $1,720.0$ & 242.4 & 335.6 & $1,828.4$ & $2,133.1$ \\
\hline BPE & 0.01 & 56.3 & 24.3 & 36.2 & 83.2 & 62.5 \\
\hline IPY & 0.1 & 616.0 & 165.2 & 457.1 & 560.5 & 747.9 \\
\hline SUM & & $12,102.2$ & $12,353.6$ & $16,693.5$ & $34,727.6$ & $46,621.6$ \\
\hline
\end{tabular}


Table 4. ILCR values of PAHs for different age groups in radish planted in five soils.

\begin{tabular}{|c|c|c|c|c|c|}
\hline & T1 & T2 & T3 & T4 & T5 \\
\hline Children & $1.3 \times 10^{-7}$ & $1.4 \times 10^{-7}$ & $1.8 \times 10^{-7}$ & $3.8 \times 10^{-7}$ & $5.1 \times 10^{-7}$ \\
\hline Adolescents & $1.1 \times 10^{-7}$ & $1.1 \times 10^{-7}$ & $1.5 \times 10^{-7}$ & $3.2 \times 10^{-7}$ & $4.2 \times 10^{-7}$ \\
\hline Adults & $7.8 \times 10^{-7}$ & $8.0 \times 10^{-7}$ & $1.1 \times 10^{-6}$ & $2.2 \times 10^{-6}$ & $3.0 \times 10^{-6}$ \\
\hline Seniors & $1.8 \times 10^{-7}$ & $1.8 \times 10^{-7}$ & $2.4 \times 10^{-7}$ & $5.0 \times 10^{-7}$ & $6.8 \times 10^{-7}$ \\
\hline
\end{tabular}

$4.0 \times 10^{-5}, 4.1 \times 10^{-5}$, and $7.1 \times 10^{-6}$ in Taiyuan, Lanzhou, and Linfen, respectively. These values suggest potential carcinogenic risks $[26,51,67-68]$. The preceding cities mentioned have high energy consumption and are heavily contaminated. The ILCR values of PAH dietary vegetable exposure for adults in other areas were higher than in T1 and T2 soils and close to the ILCR values in T3, T4, and T5 soils. Hence, more attention should be provided to the health risks of the vegetables growing in diesel-contaminated soils and heavily contaminated cities.

\section{Conclusions}

PAH concentration in radish was lower than in the soils. PAH concentration in parts of radish underground and aboveground had a significantly positive correlation with PAH concentration in soil. The composition of PAHs in the radish and soil were similar. The 2-4-ring PAHs were the predominant PAH compounds in radish. Buried parts of radish had higher PAH concentrations than parts aboveground in the same soil, and the RCF values of $\mathrm{PAHs}$ in radish were larger than $\mathrm{BCF}$ values. These results suggest that the root was key to the entry of PAH from the soil to the plant. Atmospherically deposited particles had a slight effect on $\mathrm{PAH}$ concentration in aboveground parts of radish. The total $\mathrm{TEQ}_{\mathrm{BaP}}$ in radish grown in dieselcontaminated soils was higher than in other types of soils. Therefore, no carcinogenic risks to children, adolescents, and seniors exist through the ingestion of radish planted in T1-T5 soils, while carcinogenic risks were present for adults through the ingestion of radish planted in T3, T4, and T5 soils.

\section{Acknowledgements}

This study was supported by the Special Fund for Agroscientific Research in the Public Interest (201503107) and the Shandong Provincial Natural Science Foundation (ZR2017MC068).

\section{References}

1. HUANG Y., WEI J., SONG J., CHEN M., LUO Y. Determination of low levels of polycyclic aromatic hydrocarbons in soil by high performance liquid chromatography with tandem fluorescence and diode-array detectors. Chemosphere. 92 (8), 1010, 2013.

2. MAN Y.B., KANG Y., WANG H.S., LAU W., LI H., SUN X.L., GIESY J.P., CHOW K.L., WONG M.H. Cancer risk assessments of Hong Kong soils contaminated by polycyclic aromatic hydrocarbons. Journal of Hazardous Materials. 261 (13), 770, 2013.

3. AGARWAL T., KHILLARE P.S., SHRIDHAR V., RAY S. Pattern, sources and toxic potential of PAHs in the agricultural soils of Delhi, India. Journal of Hazardous Materials. 163 (2), 1033, 2009.

4. WEI Y.L., BAO L.J., WU C.C., HE Z.C., ZENG E.Y. Association of soil polycyclic aromatic hydrocarbon levels and anthropogenic impacts in a rapidly urbanizing region: spatial distribution, soil-air exchange and ecological risk. Science of the Total Environment. 474 (3), 676, 2014

5. FU S., CHENG H.X., LIU Y.H., XIA X.J., XU X.B. Composition, distribution, and characterization of polycyclic aromatic hydrocarbons in soil in Linfen, China. Bulletin of Environmental Contamination \& Toxicology. 82 (2), 167, 2009.

6. YANG W., LANG Y., LI G. Cancer risk of polycyclic aromatic hydrocarbons (PAHs) in the soils from Jiaozhou Bay wetland. Chemosphere. 112, 289, 2014.

7. ZHANG J., YANG J.C., WANG R.Q., HOU H., DU X.M., FAN S.K., LIU J.S., DAI J.L. Effects of pollution sources and soil properties on distribution of polycyclic aromatic hydrocarbons and risk assessment. Science of the Total Environment. 463-464 (5), 1, 2013.

8. CAI Q.Y., MO C.H., LI Y.H., ZENG Q.Y., KATSOTIANNIS A., WU Q.T., FÉRARD J.F. Occurrence and assessment of polycyclic aromatic hydrocarbons in soils from vegetable fields of the Pearl River Delta, South China. Chemosphere. 68 (1), $159,2007$.

9. ZHANG Y., ZHU Y.G., HOUOT S., QIAO M., NUNAN N., GARNIER P. Remediation of polycyclic aromatic hydrocarbon (PAH) contaminated soil through composting with fresh organic wastes. Environmental Science \& Pollution Research International. 18 (9), 1574, 2011.

10. FISMES J., PERRIN G.C., EMPEREUR B.P., MOREL J.L. Soil-to-root transfer and translocation of polycyclic aromatic hydrocarbons by vegetables grown on industrial contaminated soils. Journal of Environmental Quality. 31 (5), 1649, 2002.

11. YANG Q.Q., LU S.K., WANG H.J., LI J.F, SHEN Y., ZHAN X.H. Interaction of uptake and acropetal translocation between phenanthrene and phosphate in wheat roots. Asian Journal of Ecotoxicology. 11 (3), 219, 2016.

12. WAN K., JIANG M., YANG G.Y., ZHANG T.B., GAO Y.X., WAN H.F. Distribution Characteristics of PAHs in vegetables of typical city in pearl eiver delta. Soils. 41 (4), $583,2009$.

13. KIPOPOULOU A.M., MANOLI E., SAMARA C. Bioconcentration of polycyclic aromatic hydrocarbons 
in vegetables grown in an industrial area. Environmental Pollution. 106 (3), 369, 1999.

14. MARTORELL I., PERELLÓ G., MARTÍCID R., LOBET J.M., CASTELL V., DOMINGO J.L. Human exposure to arsenic, cadmium, mercury, and lead from foods in Catalonia, Spain: temporal trend. Biological Trace Element Research. 42 (3), 309, 2011.

15. MARTÍ C.R., LLOBET J.M., CASTELL V., DOMINGO J.L. Evolution of the dietary exposure to polycyclic aromatic hydrocarbons in Catalonia, Spain. Food \& Chemical Toxicology. 46 (9), 3163, 2008.

16. FERRÉ H.N., MARTÍ C.R., SCHUHMACHER M., DOMINGO J.L. Risk Assessment of Metals from Consuming Vegetables, Fruits and Rice Grown on Soils Irrigated with Waters of the Ebro River in Catalonia, Spain. Biological Trace Element Research. 123 (3), 66, 2008.

17. INAM E., IBANGA F., ESSIEN J. Bioaccumulation and cancer risk of polycyclic aromatic hydrocarbons in leafy vegetables grown in soils within automobile repair complex and environ in Uyo, Nigeria. Environmental Monitoring \& Assessment. 188 (12), 681, 2016.

18. WANG H.C., LIN L.L., MIN L., CHEN W.F., YIN W., ZHOU J. Growth effects and accumulations of polycyclic aromatic hydrocarbons (PAHs) in rape. Chinese Journal of Plant Ecology. 37 (12), 1123, 2013.

19. WAQAS M., KHAN S., CHAO C., SHAMSHAD I., QAMAR Z., KHAN K. Quantification of PAHs and health risk via ingestion of vegetable in Khyber Pakhtunkhwa Province, Pakistan. Science of the Total Environment. 497, 448, 2014.

20. WANG J., LIU J., LING W., HUANG Q., GAO Y. Composite of PAH-degrading endophytic bacteria reduces contamination and health risks caused by PAHs in vegetables. Science of the Total Environment. 598, 471, 2017.

21. JIN X.P., JIA J.P., BI C.J., WANG X.P., GUO X.,CHEN Z.L., QIU X.L. Concentrations and Health Risk Assessment of Polycyclic Aromatic Hydrocarbons(PAHs) in Soils and Vegetables influenced by Facility Cultivation. Environmental Science. 2017.

22. LIN W., WANG G.Y., LIU F.Y. Effect of sulfur and aromatic content on diesel quality and environment. Petroleum Products Application Research. 22 (6), 14, 2004.

23. SHAMSIJAZEYI H., VERDUZCO R., HIRASAKI G.J. Reducing adsorption of anionic surfactant for enhanced oil recovery: Part II. Applied aspects. Colloids \& Surfaces A Physicochemical \& Engineering Aspects. 453 (1), 168, 2014.

24. KHAN S., AI J.L., ZHANG S., HU Q., ZHU Y.G. Accumulation of polycyclic aromatic hydrocarbons and heavy metals in lettuce grown in the soils contaminated with long-term wastewater irrigation. Journal of Hazardous Materials. 152, 506, 2008

25. NISBET I.C., LAGOY P.K. Toxic equivalency factors (TEFs) for polycyclic aromatic hydrocarbons (PAHs). Regulatory Toxicology \& Pharmacology. 16 (3), 290, 1992.

26. XIA Z.H., DUAN X.L., QIU W.X., LIU D., WANG B., TAO $\mathrm{S}$. Health risk assessment on dietary exposure to polycyclic aromatic hydrocarbons (PAHs) in Taiyuan, China. Science of the Total Environment. 408 (22), 5331, 2010.

27. MA G., ZHAO L. Monitoring Report on Nutrition and Health Status of Chinese Residents. 2014.

28. NI H.G., GUO J.Y. Parent and halogenated polycyclic aromatic hydrocarbons in seafood from South China and implications for human exposure. Journal of Agricultural \& Food Chemistry. 61 (8), 2013, 2013.
29. ZHAO Z., ZHANG L., CAI Y., CHEN Y. Distribution of polycyclic aromatic hydrocarbon $(\mathrm{PAH})$ residues in several tissues of edible fishes from the largest freshwater lake in China, Poyang Lake, and associated human health risk assessment. Ecotoxicology \& Environmental Safety. 104 (2), 323, 2014

30. XU Y., ZHANG W., YANG R., ZOU C., ZHAO Z. Infant mortality and life expectancy in China. Medical Science Monitor International Medical Journal of Experimental \& Clinical Research. 20 (3), 379, 2013.

31. MALISZEWSKA K.B. Polycyclic aromatic hydrocarbons in agricultural soils in Poland: preliminary proposals for criteria to evaluate the level of soil contamination. Appl. Geochem. 11 (1-2), 121, 1996.

32. PAN F., GENG Q.J., CHU H.J., WANG L.L. Analysis of polycyclic aromatic hydrocarbons in petroleum contaminated soils and its ecological risk assessment. Journal of Ecology \& Rural Environment. 27 (5), 42, 2011.

33. YUAN J.P., WANG X.L., ZHOU J.B., CHEN X.F., ZHAO R.S., CHENG C. Distribution, source and risk analysis of polycyclic aromatic hydrocarbons in top-soil from Jinan City. Environmental Chemistry. 1, 166, 2015.

34. QI J.C., ZHANG C.D., QIAO J., GUO T., ZHANG Q.M., CHEN W. Bioremediation of Petroleum-Contaminated Soil by Mixed Microbes and Organic Fertilizer. Journal of Agro - Environment Science. 29 (1), 66, 2010.

35. CHEN Z.X., NI H.G., JING X., CHANG W.J., SUN J.L., ZENG H. Plant uptake, translocation, and return of polycyclic aromatic hydrocarbons via fine root branch orders in a subtropical forest ecosystem. Chemosphere. 131, 192, 2015.

36. SHEN Y.Y., TENG Y., LUO Y.M., SUN M.M., FU D.Q., SHEN X.F., LI Z.G. Remediation efficiency of several legumes and grasses in PAH-contaminated soils. Soils. 43 (2), 253, 2011

37. WANG Y., WANG S.R., LUO C.L., XU Y., PAN S.H., LI J., MING L.L., ZHANG G., LI X.D. Influence of rice growth on the fate of polycyclic aromatic hydrocarbons in a subtropical paddy field: A life cycle study. Chemosphere. 119 (1), 1233, 2015.

38. CAO Q.M., WANG H., ZHANG Y.B., LIU Z.W., ZHANG G.Y., ZHAO C.M. Characters of uptake and accumulation of polycyclic aromatic hydrocarbons (PAHs) in pakchoi cabbage in tropical latosol. Ecology and Environmental Sciences. 23 (9), 1478, 2014

39. YIN C.Q., JIANG X., YANG X.L., WANG C.Y., BIAN Y.R., WANG F. Characters of soil-vegetable transfer and accumulation of polycyclic aromatic hydrocarbons. Environmental Science. 29 (11), 3240, 2008.

40. SHEN F., ZHU L.Z. Concentration and distribution of PAHs in vegetables grown near an iron and steel industrial area. Environmental Science. 28 (3), 669, 2007.

41. ZHANG T., WAN H.., YANG G., GAO Y., LUO W. Distribution of polycyclic aromatic hydrocarbons in agricultural soil and vegetables of Foshan City in the Pearl River Delta. Acta Scientiae Circumstantiae. 28 (11), 2375, 2008.

42. YU W., KUANG S., ZHAO L. Uptake, accumulation and translocation of polycyclic aromatic hydrocarbons by winter wheat cultured on oily sludge-amended soil. Chinese Journal of Geochemistry. 32 (3), 295, 2013.

43. NAVARROORTEGA A., RATOLA N., HILDEBRANDT A., ALVES A., LACORTE S., BARCELO D. Environmental distribution of PAHs in pine needles, soils, and sediments. Environmental Science \& Pollution Research International. 19 (3), 677, 2012. 
44. GAO H.J., WEI J.L., MA J.J., ZHENG B. Characteristics of PAHs contamination in soil and vegetable in typical city outskirt of anhui province, China. Journal of AgroEnvironment Science. 31 (10), 1913, 2012.

45. ZHANG J., FAN S., DU X., YANG J., WANG W., HOU H. Accumulation, allocation, and risk assessment of polycyclic aromatic hydrocarbons (PAHs) in soil-Brassica chinensis System. Plos One. 10 (2), 2015

46. MA W.L., LI Y.F., QI H., SUN D.Z., LIU L.Y., WANG D.G. Seasonal variations of sources of polycyclic aromatic hydrocarbons (PAHs) to a northeastern urban city, China. Chemosphere. 79 (4), 441, 2010.

47. SOJINU O.S., SONIBARE O.O., EKUNDAYO O., ZENG E.Y. Biomonitoring potentials of polycyclic aromatic hydrocarbons (PAHs) by higher plants from an oil exploration site, Nigeria. Journal of Hazardous Materials. 184 (1-3), 759, 2010

48. CHEN H.Y., TENG Y.G., WANG J.S. Source apportionment for sediment PAHs from the Daliao River (China) using an extended fit measurement mode of chemical mass balance model. Ecotoxicology \& Environmental Safety. 88 (2), 148, 2013.

49. REID B.J., JONES K.C., SEMPLE K.T. Bioavailability of persistent organic pollutants in soils and sediments - a perspective on mechanisms, consequences and assessment. Environmental Pollution. 108 (1), 103, 2000.

50. ZHANG J., FAN S.K. Influence of PAH speciation in soils on vegetative uptake of PAHs using successive extraction. Journal of Hazardous Materials. 320, 114, 2016.

51. KHILLARE P.S., JYETHI D.S., SARKAR S. Health risk assessment of polycyclic aromatic hydrocarbons and heavy metals via dietary intake of vegetables grown in the vicinity of thermal power plants. Food \& Chemical Toxicology. 50 (5), 1642, 2012.

52. WANG J., XIANG J., HAN L., ZHAO F., AI L. Determination of 16 kinds of polycyclic aromatic hydrocarbons in vegetables. Journal of Food Safety and Quality. 7 (12), 4878, 2016.

53. DUAN F., KEBIN H.E. Concentration and sources of atmospheric polycyclic aromatic hydrocarbons (PAHs) in $\mathrm{PM}_{25}$ in Beijing. Acta Scientiae Circumstantiae. 29 (7), $1363,2009$.

54. HU Y., ZHENG L.G., CHENG H., CHEN Y.C., YANG Y., GE Y.J., KONG L.J. Characteristics and source identification of polycyclic aromatic hydrocarbons (PAHs) in PM2. 5 in Huainan city. Environmental monitoring management and technology. 28 (6), 33, 2016.

55. LIU X., PENG L., BAI H., MU L., SONG C. Gas/particle distribution characteristics of polycyclic aromatic hydrocarbons in coke plant atmosphere. Journal of Jiangsu University: Natural Science Edition. 34 (2), 228, 2013.

56. LI W.H., ZHANG C.Z., MA W.L., ZHOU B.H., LIU Y.M., JIANG J.L., LI Y.F. Pollution characterizations and source apportionment of polycyclic aromatic hydrocarbons in air during domestic heating season of Xi'an. Environmental Science. 31 (7), 1432, 2010.

57. LI J., SHANG X., ZHAO Z., TANGUAY R.L., DONG Q., HUANG C. Polycyclic aromatic hydrocarbons in water, sediment, soil, and plants of the aojiang river waterway in Wenzhou, China. Journal of Hazardous Materials. 173 (1-3), 75, 2010.

58. HONG Y.W., CHEN J.S., ZHANG F.W., ZHANG H., XU L.L., YIN L.Q., CHEN Y. T. Effects of urbanization on gaseous and particulate polycyclic aromatic hydrocarbons and polychlorinated biphenyls in a coastal city, China: levels, sources, and health risks. Environmental Science \& Pollution Research. 22 (19), 14919, 2015.

59. WILD S.R., BERROW M.L., MCGRATH S.P., JONES K.C. Polycyclic aromatic hydrocarbons in crops from long-term sewage sludge amended field experiments. Environmental Pollution. 6 (1), 25, 1992.

60. TAO S., CUI Y.H., XU F.L., LI B.G., CAO J., LIU W.X., SCHIMITT G., WANG X.J., SHEN W.R., QING B.P., SUN R. Polycyclic aromatic hydrocarbons (PAHs) in agricultural soil and vegetables from Tianjin. Science of the Total Environment. 320 (1), 11, 2004.

61. WANG Y.C. Contamination characterization and health risk assessment of heavy metals and polycyclic aromatic hydrocarbon in soils and vegetables from typical wastewater irrigated areas. 2012.

62. XIONG G.N., ZHANG Y.H., DUAN Y.H., CAI C.Y., WANG Y., LI J.Y., TAO S., LI W.X. Impacts of polycyclic aromatic hydrocarbons emitted by coking industry on cabbages from neighboring vegetable plots in Jinzhong County, Shanxi Province. Asian Journal of Ecotoxicology. 11 (2), 473, 2016.

63. ZHANG T. Pollution and source Identification of polycyclic aromatic hydrocarbons in atmosphere of Qingdao, China. Ocean University of China. 2007.

64. SIMONICH S.L., HITES R.A. Organic Pollutant Accumulation in Vegetation. Environmental Science \& Technology. 29 (12), 2905, 1995.

65. AMYMARIE A.D., GSCHWEND P.M. Assessing the combined roles of natural organic matter and black carbon as sorbents in sediments. Environmental Science \& Technology. 36 (1), 21, 2002.

66. QIAO L. The content and health risk of polycyclic aromatic hydrocarbons in soil and vegetables in Families of Southern. 2011.

67. YIN J., XIA Z., ZHOU Y., WU M., ZHANG Q., YANG $\mathrm{H}$. Characterization and cancer risk assessment of PAHs in vegetables sold in Linfen City, China. Asian Journal of Ecotoxicology. 11 (3), 265, 2016.

68. DONG J.Y., WANG J.Y., ZHANG G.X., WANG S.G., SHANG K.Z. Exposure and health risk assessment of polycyclic aromatic hydrocarbons (PAHs) in Lanzhou. Ecology and Environmental Sciences. 21 (2), 327, 2012. 
